\title{
The influence of slurry density on in situ density
}

\author{
D Reid Golder Associates Pty Ltd, Australia
}

AB Fourie The University of Western Australia, Australia

\begin{abstract}
Since the beginning of the Paste and Thickened Tailings seminar series, there has been ongoing discussion as to whether an increase in the deposited (initial) slurry density will result in an increased density at depth within an accreting deposit, all else being equal. Despite frequent speculation and theorising, there has been relatively little laboratory data or other evidence presented at the conference series to address this question.
\end{abstract}

To address the above deficiency, a literature review was undertaken to identify experimental programs where the same material was prepared for soil testing from different initial slurry densities. Twelve such studies were identified, of which nine indicate that an increase in initial slurry density resulted in increased density at subsequent significant vertical effective stresses. Case studies presented on three tailings deposits are investigated, to assess the implications of the presented results on the potential for initial slurry density to influence in situ density. For many of the studies reviewed, there appears to be an indication that an increased initial slurry density resulted in an increased in situ density at significant vertical effective stresses. Finally, a series of consolidation tests were undertaken by the authors, wherein four tailings types were prepared from different non-segregating initial slurry densities. For three of these materials, a dependence on situ density was observed, based on changes to initial slurry density.

On the basis of the review and experimental data presented in this study, the authors conclude that for at least some materials, initial slurry density can result in an increased density across a wide range of vertical effective stresses.

\section{Introduction}

Throughout the Paste and Thickened Tailings seminar series, there has been ongoing discussion as to whether a thickened slurry (as opposed to conventional, lightly thickened slurries) results in higher in situ densities, and if so, to what depth such changes may be realised. The authors have heard two general hypotheses suggested by a number of colleagues and fellow practitioners:

- Hypothesis A: that increasing initial (where 'initial' refers to the end-of-pipe condition) slurry density may result in slightly increased density at shallow depths, possibly resulting from an earlier initiation of air drying, but that at increasing stress/depth the normal consolidation line $(\mathrm{NCL})$ of materials prepared at different slurry densities will converge.

- Hypothesis B: that increasing initial slurry density can result in a NCL that will be different from the NCL obtained from a thinner slurry, i.e. the normal consolidation lines will not converge (at least for values of effective stress that are realistically attainable in a typical storage facility).

The two general schools of thought are shown schematically in Figure 1.

Hypothesis A has been suggested by Barrera and Riveros (2006). It has also been explicitly outlined by Fitton and Seddon (2013), who state that following incremental deposition and settling on a thickened tailings deposit "there is a thin layer of tailings on the beach, at a density that is independent of the concentration of the slurry it was deposited from. All subsequent drying and consolidation processes are independent of the initial slurry density". Hypothesis B was suggested by Li et al. (2009) and Reid and Fourie (2014), based on a laboratory data available in those studies. 
Hypothesis A

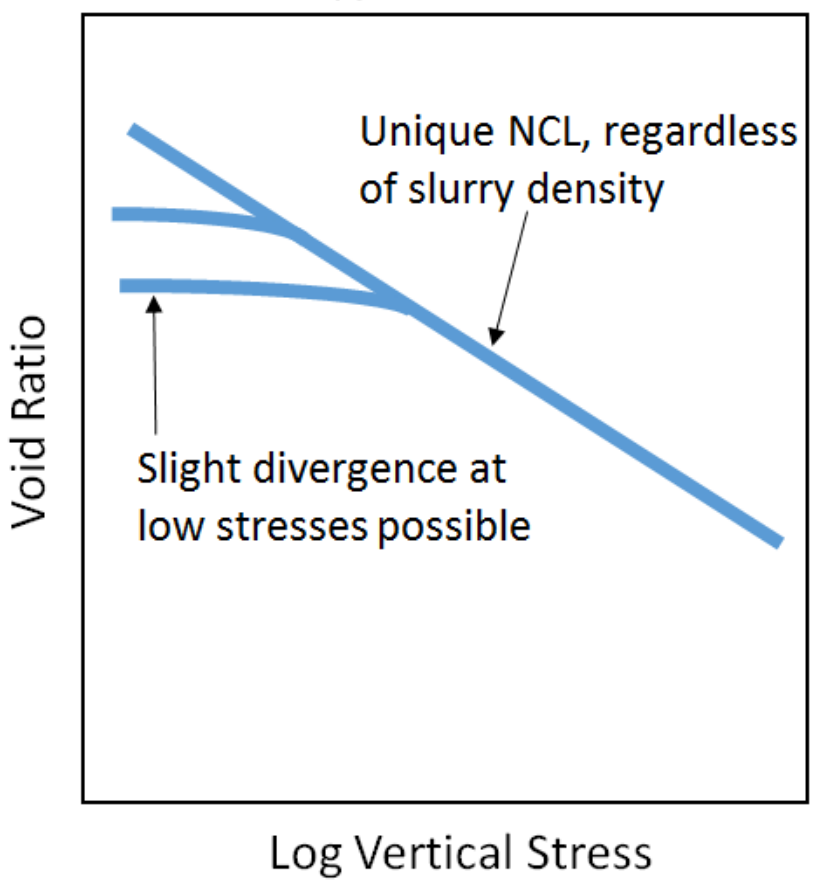

Hypothesis B

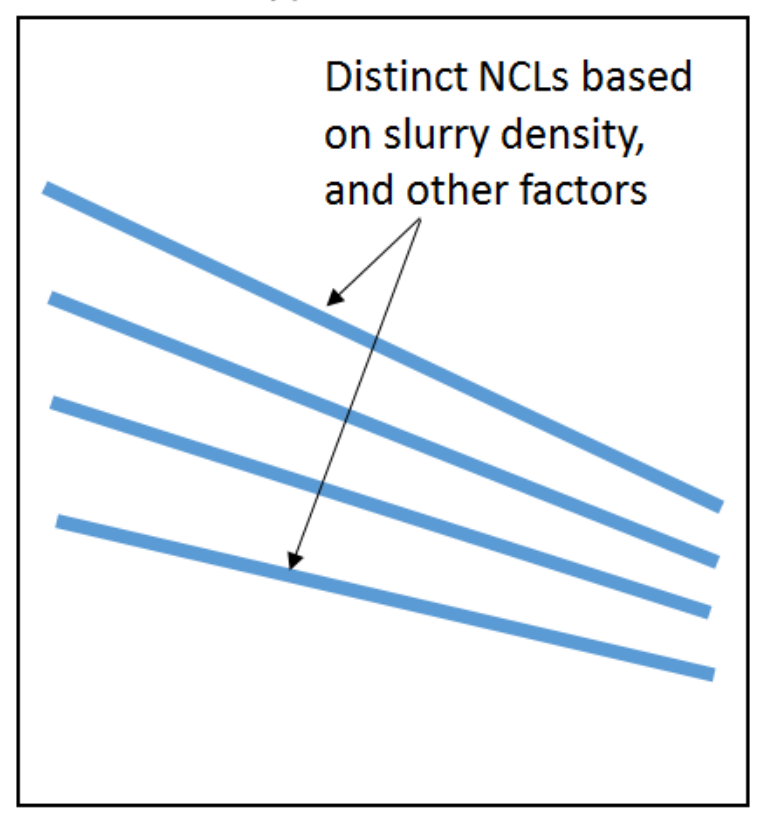

Log Vertical Stress

\section{Figure 1 Comparison of Hypotheses A and B}

In an attempt to critically assess the two hypotheses presented, a literature review of published laboratory testing conducted on material from different initial slurry densities was undertaken, relevant full-scale data analysed, and additional experiments on three tailings types undertaken. This is presented below.

It is noted that the question posed in this paper is not of purely academic interest - if Hypothesis B is correct, that would suggest an increased liquefaction resistance and storage efficiency of thickened tailings deposits, based purely on the NCL achieved in situ on the basis of initial slurry density.

The two hypotheses examined herein are distinct from the following well-established observations in the geotechnical literature:

- Preparation of samples in the laboratory using different techniques (air pluviation, water pluviation, moist tamping), or applying the same technique with different drop heights or compactive effort (for example), can result in unique NCLs for soils. This has been well established in the geotechnical literature (e.g. Ishihara 1993; Vaid \& Sivathayalan 2000; Jefferies \& Been 2000). In this study, it is assumed that deposition of a slurry at different densities is of sufficiently similar 'sample preparation' methods that a unique NCL on the basis of fabric cannot be assured.

- Preparation of slurries with different pore fluid chemistries can result in drastically different NCLS across a range of vertical effective stresses (Wang \& Siu 2006; Sachan \& Penumadu 2007; Inparajah \& Wong 2008; Knop et al. 2009; Siddique \& Blatz 2009; Meijer \& Dijkstra 2013). While well established, this observation is not directly relevant to this study, where the only variable under consideration is a change in initial slurry density.

\section{$2 \quad$ Available experimental data}

To assess the potential impacts of initial slurry density on resulting consolidation behaviour, the geotechnical literature was reviewed to assess where this question may have been addressed previously. While tailings and natural soils differ in many ways, because both are particulate media governed by the effective stress concept and can be prepared similarly from an initial slurry consistency, there is no reason to exclude natural soils from consideration. 
Hypothesis A was found to be supported by studies undertaken by Berilgen et al. (2006), Nocilla et al. (2006), and Filho and Menezes (2012). In each of these studies, all consolidation tests converged on a single unique NCL at relatively low stresses, regardless of initial slurry density. Hypothesis $B$ was found to be supported by the studies outlined in Table 1. For each material shown in Table 1, significant and consistent differences in density were observed at a wide range of stresses. It is noted that many of the studies cited were published in the leading geotechnical peer-reviewed journals, and major conferences related to consolidation and tailings. This suggests that many in the geotechnical profession implicitly accepted that Hypothesis B is valid, at least in some cases. The average increase in density seen from increasing initial slurry density in the laboratory data presented is $13 \%$. It is interesting to note that this increase is quite similar to the density increases presented from case histories where tailings deposition converted from conventional to thickened deposition (McPhail et al. 2004; Kam 2011; Fourie 2012).

\section{Table 1 Published experimental data supporting Hypothesis B}

\begin{tabular}{|c|c|c|c|}
\hline Reference & $\begin{array}{l}\text { Soil or tailings } \\
\text { description }\end{array}$ & $\begin{array}{l}\text { Range of slurry } \\
\text { density tested } \\
\text { (\% solids by } \\
\text { mass) }\end{array}$ & $\begin{array}{l}\text { Resulting range in dry density } \\
\left(\mathrm{t} / \mathrm{m}^{3}\right) \text { at } 100 \mathrm{kPa} \text { vertical } \\
\text { effective stress (unless } \\
\text { otherwise stated) }\end{array}$ \\
\hline Takada \& Mikasa (1986) & Dredged clay & $40-45$ & $0.90-0.92 *$ \\
\hline Aydilek et al. (2000) & Wastewater sludge & $25-30$ & $0.37-0.50 * *$ \\
\hline Martins et al. (2001) & Residual clayey sand & $74-80$ & $1.44-1.83$ \\
\hline Nocilla et al. (2006) (1) & Italian silt & $63-75$ & $1.30-1.56$ \\
\hline Nocilla et al. (2006) (2) & Italian silt & $67-71$ & $1.24-1.37$ \\
\hline Li et al. (2009) & Tailings & Not given & $1.56-1.64 * * *$ \\
\hline Hong et al. (2010) & Clay & $41-61$ & $1.00-1.18$ \\
\hline Al-Tarhouni et al. (2011) & Gold tailings & $73-76$ & $1.72-1.80$ \\
\hline Sanin et al. (2012) & Copper-gold tailings & $63-74$ & $1.65-1.71$ \\
\hline Bonin et al. (2014) & Gold tailings & $70-71$ & $1.60-1.62$ \\
\hline
\end{tabular}

It is acknowledged by the authors that the list provided herein is not comprehensive. Studies which include data to support either hypothesis are generally related to other topics, with the consolidation results only a small portion of the work. This has made the search for relevant studies difficult.

It is also noted that in many of the references provided in Table 1, the authors include explicit statements that the range of slurry densities used did not result in segregation. Further, the range of slurry densities when viewed in relation to the type of material suggest that for most studies cited segregation was unlikely to have occurred. The influence of segregation on the arguments regarding the two hypotheses outlined earlier are discussed further below.

\section{Insights from full-scale behaviour}

\subsection{General}

As noted above, case studies have been presented in the literature suggesting that transitioning a tailings from conventional to thickened deposition resulted in density increases of 8-10\% (McPhail et al. 2004; Kam 2011; Fourie 2012). However, case studies present difficulties when used to try to answer the underlying 
question of this paper. Thickened tailings often commence air drying sooner than conventional tailings, as they may have little or no initial bleed water, whereas a conventionally deposited material must first undergo significant settling. Further, the reduction of particle segregation in a thickened tailings means that the materials compared may not be the same - even if in both cases the index properties were identical at the point of discharge. For example, samples taken in a conventional tailings deposit will likely vary laterally owing to segregation, whereas a thickened deposit may not. Material with the full tailings gradation is likely to produce a more efficient packing arrangement than segregated material. For these reasons, it if often difficult to use full-scale results to address the question raised in this paper.

Despite the difficulties in the use of full-scale behaviour as discussed, three examples from the literature are presented of conventional and thickened tailings deposits, where field data and laboratory tests together may provide some insight into the question posed in this paper.

\subsection{Merriespruit}

Merriespruit was an upstream-raised gold tailings deposit in South Africa that underwent a tragic failure in 1994 resulting in 17 deaths. As a result of the failure, a number of detailed post-failure investigations were undertaken (Wagener 1997; Wagener et al. 1998; Strydom \& Williams 1999; Fourie et al. 2001; Fourie \& Papageorgiou 2001; Papageorgiou 2004).

Of relevance to this study, the investigations of Merriespruit included tube sampling in unfailed parts of the beach and exposed tailings (Fourie \& Papageorgiou 2001). These samples indicated a loose state, significantly higher (i.e. looser) than the relevant critical state line (CSL) for the gradation of the material. Further, testing of some of these undisturbed samples recovered from adjacent to the failure indicated contractive behaviour (Wagener et al. 1998), consistent with a material looser than the CSL. However, when samples were prepared in the laboratory from a thick, non-segregating slurry (a requirement of laboratory element testing), they produced densities below the relevant CSL, and exhibited dilative behaviour. This is inconsistent with the field data from Merriespruit. It suggests that the very low slurry density which often occurred at Merriespruit, possibly combined with the pluviation of the tailings through 'dirty' ponded water (Vaughn 1997).

It is noted that the average rate of rise of Merriesupruit was less than $2 \mathrm{~m} /$ year. Given the conceivable range of consolidation properties for hard rock gold tailings, the self-weight consolidation process within the material would have been largely complete. Indeed, in situ pore pressures were seen to be lower than hydrostatic (Wagener et al. 1998). Therefore, while the in situ state of the tailings at Merriespruit (and other loose deposits) has often been referred to as 'poorly consolidated' or 'unconsolidated', these terms introduce confusion - the material had completed primary consolidation, albeit on a loose NCL. The loose $\mathrm{NCL}$ is suggested to be a result of the low slurry density at deposition combined possibly with pluviation through water near the perimeter of the facility.

To provide an additional estimate of the in situ state of the Merriespruit tailings in relation to the CSL and non-segregating slurry NCL, Cone Penetration Test (CPT) data presented by Wagener et al. (1998) was interpreted by the authors. The distance between the current void ratio and that at the CSL, referred to as state parameter $\psi$ (Been \& Jefferies 1985) was assessed based on techniques proposed by Been et al. (1988), with site-specific parameters obtained from the range of CSLS presented by Fourie and Papageorgiou (2001). This is presented in Figure 2. The dense and loose estimates were based on the range of compressibilities indicated by the CSL testing.

The inferred in situ states are generally loose, with densities as loose as, or possibly looser than those obtained through moist tamping. While moist tamping is the laboratory technique expected to produce loosest samples, it is noted that in situ states potential looser than those possible from moist tamping have been noted elsewhere (Shuttle \& Cunning 2007) in fine grained deposits pluviating through water during deposition. 


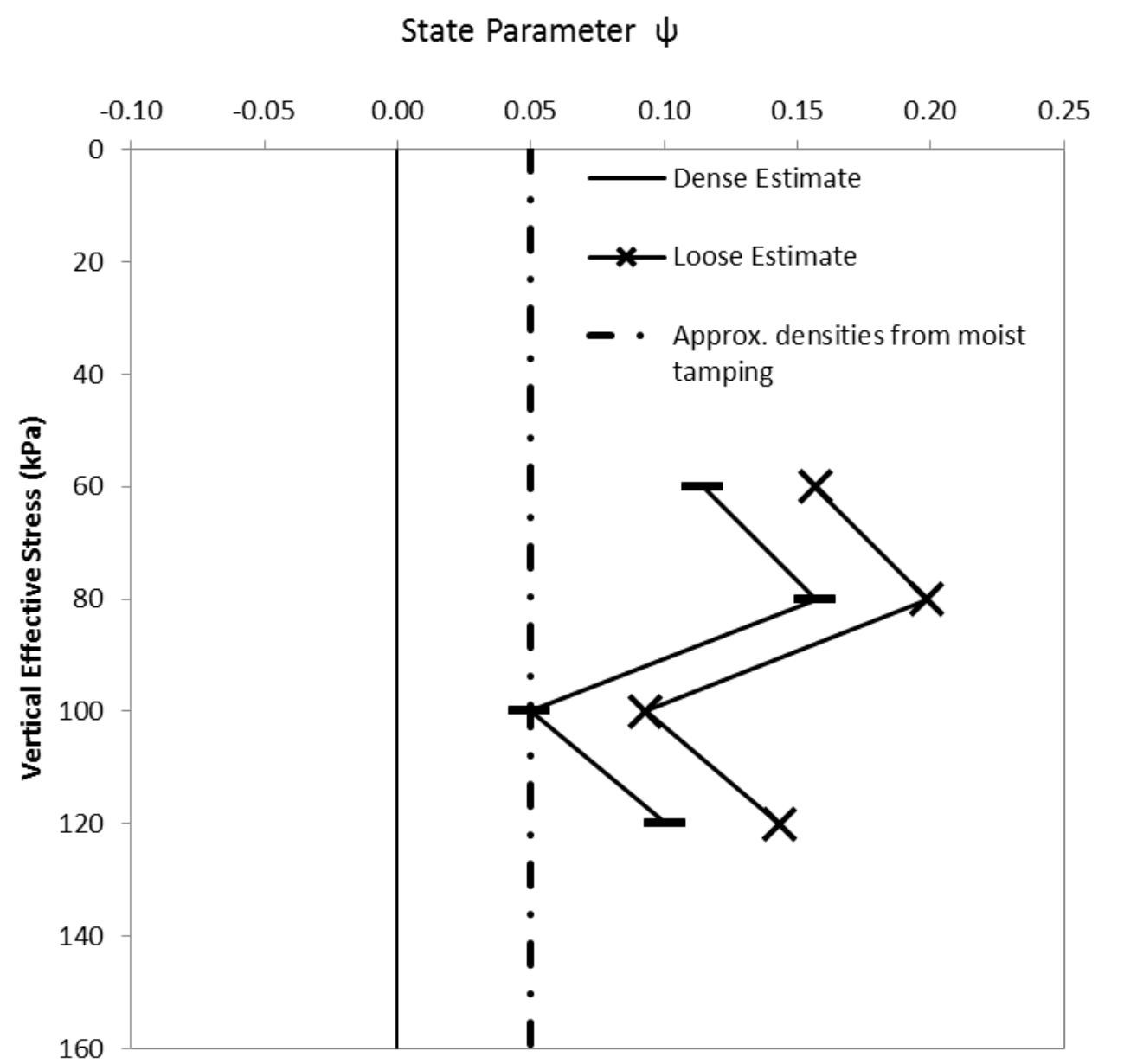

Figure 2 Inferred state of Merriespruit tailings (CPTu PE7A, after Wagener et al. 1998)

\subsection{Osborne}

Osborne is a copper-gold mine, where tailings deposition was converted from conventional to thickened (McPhail et al. 2004; McPhail \& Brent 2007). Material deposited at the time of the conversion was typically $60 \%$ fines $(<75 \mu \mathrm{m})$ and non-plastic. As part of the assessment of the feasibility of developing a steepened beach slope from thickening, the CSL and NCL of the tailings were obtained through laboratory testing. The NCL was obtained through Rowe Cell (Rowe \& Barden 1966) testing of the slurry, poured into the cell at the expected depositional slurry density of $72 \%$ solids. This indicated a relatively dense NCL, plotting below the CSL. This result is similar to that obtained for Merriespruit tailings tested from a dense slurry.

The dense state inferred from the testing outlined by McPhail et al. (2004) provides circumstantial evidence to the effects of slurry density on in situ density. The observed behaviour of other non-plastic tailings of similar gradations such as Merriespruit, when deposited at low slurry densities, suggests that a looser state would result for Osborne tailings under such circumstances.

The in situ state of the Osborne tailings are presented in Figure 3. State parameter was estimated using the same techniques as for Merriespruit. All of the CPT data available from McPhail et al. (2004) and McPhail and Brent (2007) were utilised. Also, the estimated in situ state parameter on the basis of the laboratory comparison of NCL and CSL is included for comparison.

While significant scatter is evident in the CPT-derived estimates, the majority of the data indicates a state slightly denser than that predicted in the laboratory prior to deposition. This may be a result of air drying densification or overconsolidation on the beach, of varied material properties over time, or of limitations in the inference of state parameter in situ from a single set of CSL data. Regardless, it is clear that the vast majority of the in situ materials are in a dilative state. 


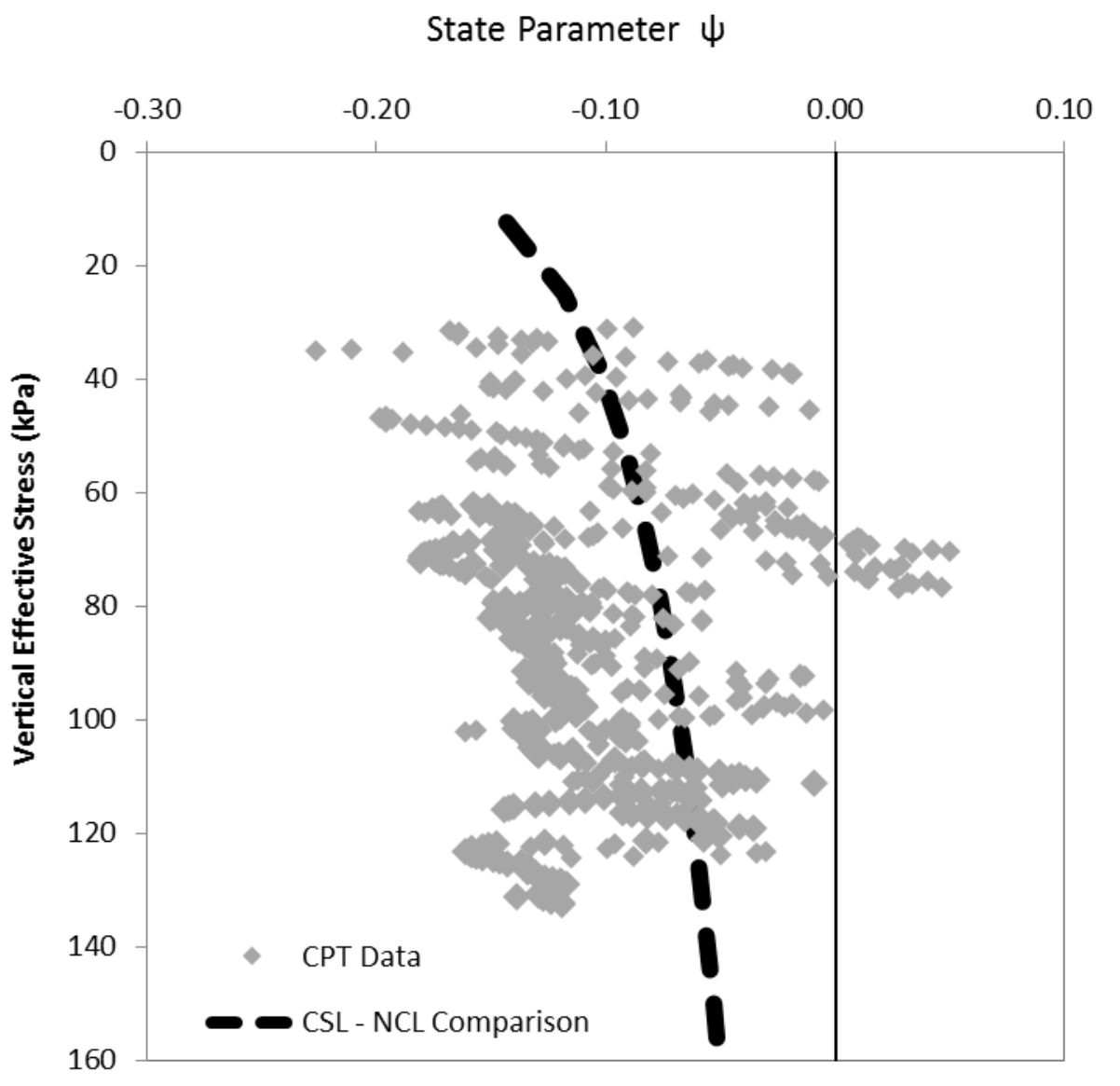

Figure 3 Inferred state of Osborne tailings

\subsection{South African gold tailings}

Chang et al. (2011) undertook laboratory tests where samples of a South African Gold Tailings were remoulded to similar densities to those obtained in situ through tube sampling. However, for two of the gradations tested in this manner, slurry deposition by means of a thick non-segregating slurry was unable to reproduce the loose states sampled in situ. The tailings at the deposit investigated were deposited conventionally, and hence at a lower slurry density than the thick consistency used in the laboratory samples. This suggests that for the tailings in question, the NCL was dependent on initial slurry density.

It is also interesting to consider that the in situ material, created from settling-out of a segregating tailings stream, would be difficult to reproduce in the laboratory. The in situ gradation of samples, which typically varies along the beach, is a result of the segregation process on the beach. Therefore, taking a disturbed sample from a location, remoulding it to the tailings initial slurry density, and pouring it into a mould or similar would likely result in further segregation of the material with sands dropping to the bottom and fines remaining on the surface This variable material would no longer be representative of the material sampled from the beach.

\subsection{Synthesis of results}

The in situ tailings outlined above share many similarities, with all being non-plastic and in the range of 40-60\% fines. Yet they exhibit drastically different in situ states, at vertical effective stresses in excess of $100 \mathrm{kPa}$. We suggest that the dramatic difference in the in situ state of the deposits was largely a result of the different depositional solids concentration and settling conditions of the materials. Merriespruit in particular was deposited at very low slurry densities, and in many cases pluviated through water during deposition. Osborne was deposited at a thick slurry density, and much of the material may have undergone 
air drying. These differences in deposition indicate significantly different states, from a variety of different laboratory and in situ test techniques.

While air drying may have contributed to the denser states at Osborne, the laboratory CSL and NCL indicated that this was not a prerequisite to attaining a dilative condition. Further, the benefits of air drying on increased density at high vertical effective stress are not clear (Al-Tarhouni et al. 2011).

\section{$4 \quad$ Laboratory testing}

\subsection{Materials and methods}

To produce further data relevant to the effects of slurry density on in situ densities, consolidation testing was undertaken on iron ore, lateritic nickel, and two gold tailings. There are available studies that have presented settling tests where the mass of solids was specifically controlled to enable improved comparisons of settled density (e.g. Salfate 2011), which indicate that slurry density can influence settled density. However, given the inherent limitations of settling tests (e.g. Fitton \& Seddon 2013), we focussed the experimental study on consolidation tests.

Each material presented was already undergoing testing for other purposes at a specific initial slurry density relevant to field conditions. Therefore they provided a useful source to perform additional tests to assess the effects of initial slurry density. The results of some of the testing on one of the gold tailings (1) and the iron ore tailings were previously reported by Reid and Fourie (2014), while further details regarding the lateritic nickel tailings are outlined by Reid and Boshoff (2015).

\section{Table 2 Materials tested}

\begin{tabular}{|c|c|c|c|c|}
\hline $\begin{array}{l}\text { Tailings } \\
\text { type }\end{array}$ & $\begin{array}{c}\text { Test apparatus } \\
\text { used }\end{array}$ & $\begin{array}{l}\text { \% Fines } \\
(<75 \mu \mathrm{m})\end{array}$ & $\begin{array}{l}\text { Atterberg limits (liquid } \\
\text { limit/plasticity index) }\end{array}$ & $\begin{array}{c}\text { Slurry densities tested } \\
\text { (\% solids by mass) }\end{array}$ \\
\hline Gold (1) & $\begin{array}{l}63 \mathrm{~mm} \text { diameter } \\
\text { oedometer }\end{array}$ & 54 & Non-plastic & 71 and 75 \\
\hline Gold (2) & $\begin{array}{l}71 \mathrm{~mm} \text { slurry } \\
\text { consolidometer }\end{array}$ & 67 & Non-plastic & 63 and 73 \\
\hline Iron ore & $\begin{array}{c}63 \mathrm{~mm} \text { diameter } \\
\text { oedometer }\end{array}$ & 69 & $27 / 8$ & 63 and 69 \\
\hline $\begin{array}{l}\text { Lateritic } \\
\text { nickel }\end{array}$ & $\begin{array}{l}71 \mathrm{~mm} \text { slurry } \\
\text { consolidometer }\end{array}$ & 87 & $55 / 7$ & 30 and 38 \\
\hline
\end{tabular}

Consolidation tests were undertaken using either a $63 \mathrm{~mm}$ diameter oedometer, or a $71 \mathrm{~mm}$ diameter slurry consolidometer (Sheeran \& Krizek 1971), dependent on availability. Consolidation tests did not proceed far enough beyond the end of primary consolidation to develop creep parameters, owing to time considerations. The pore fluid of the lateritic nickel tailings was hypersaline, with a salt concentration of $247 \mathrm{~g}$ of salt per $\mathrm{L}$ of water. Both tests were undertaken from the same batch of slurry, with the same pore fluid. Salt corrections have been made using identical techniques for each.

\subsection{Results}

The results of the consolidation testing are presented in Figures 4, 5, and 6 . The consolidation testing of the lateritic nickel, iron ore, and gold (2) tailings at different initial slurry densities resulted in unique NCLs up to at least $500 \mathrm{kPa}$ vertical effective stress. Convergence was seen with increasing stress in both instances, but despite this the NCLs remained distinct. For the gold (1) tailings, an essentially identical NCL was observed for both samples as indicated in Figure 5. 


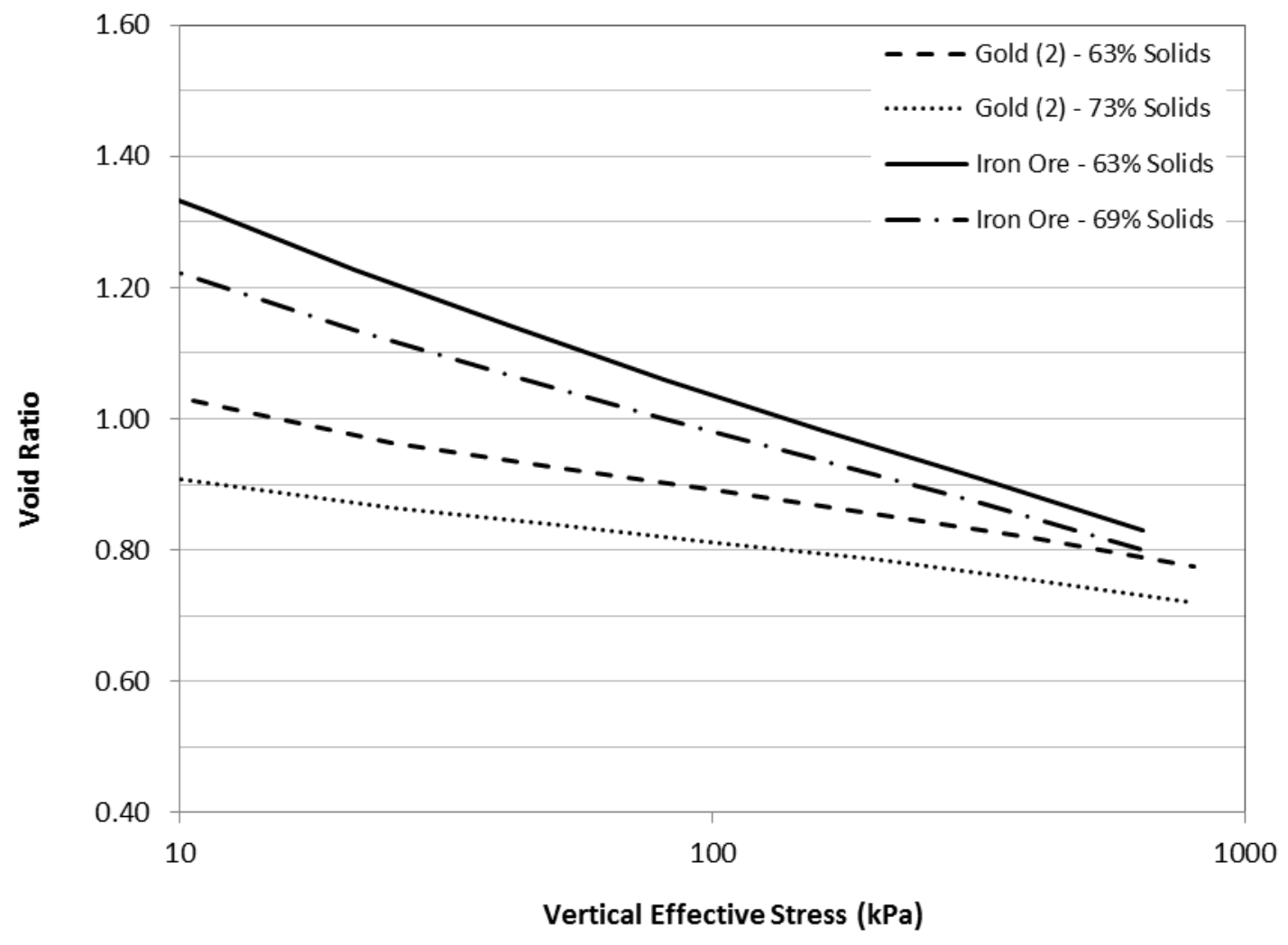

Figure 4 Iron ore and gold (2) tailings consolidation results

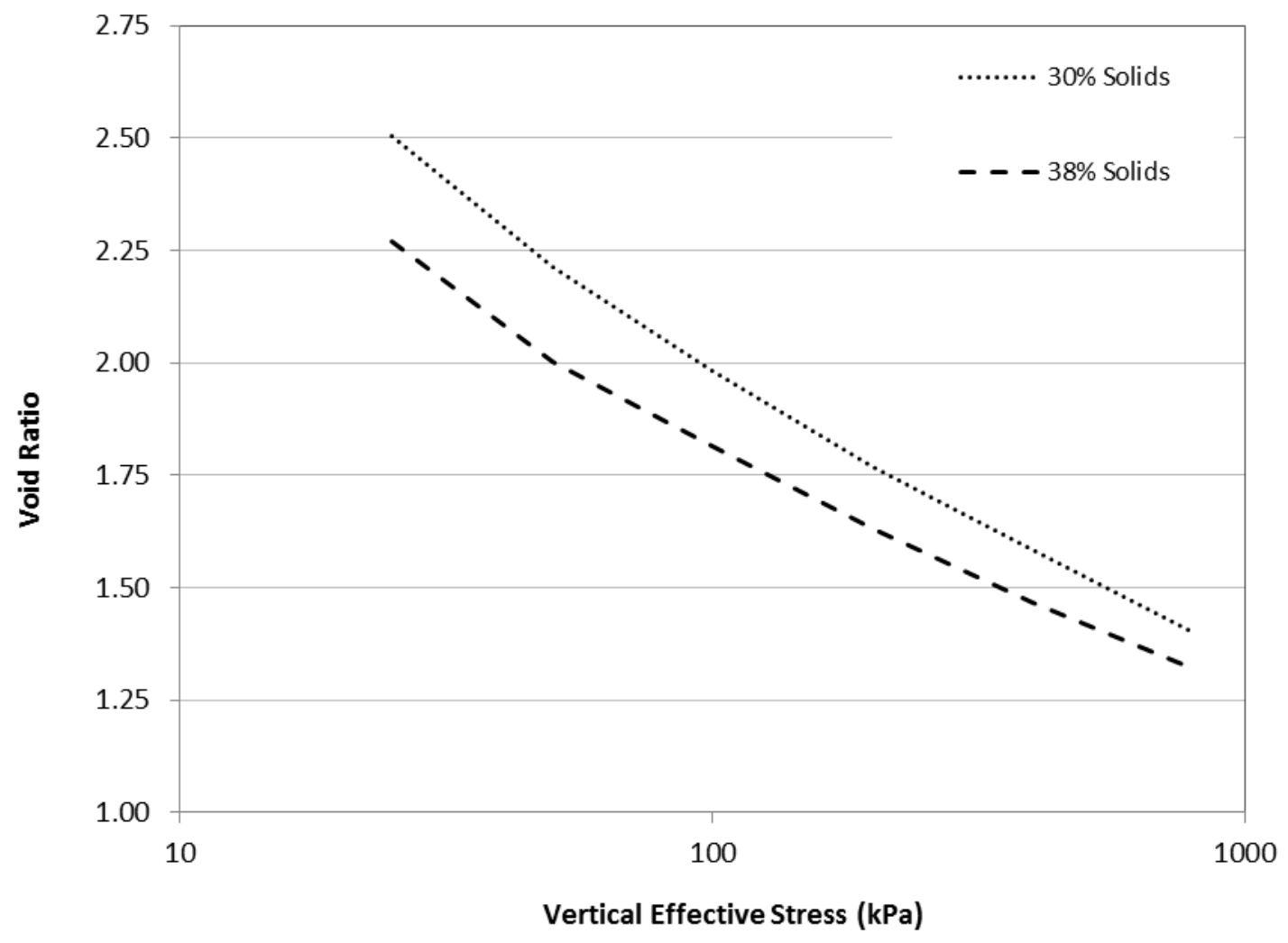

Figure 5 Lateritic nickel consolidation results 


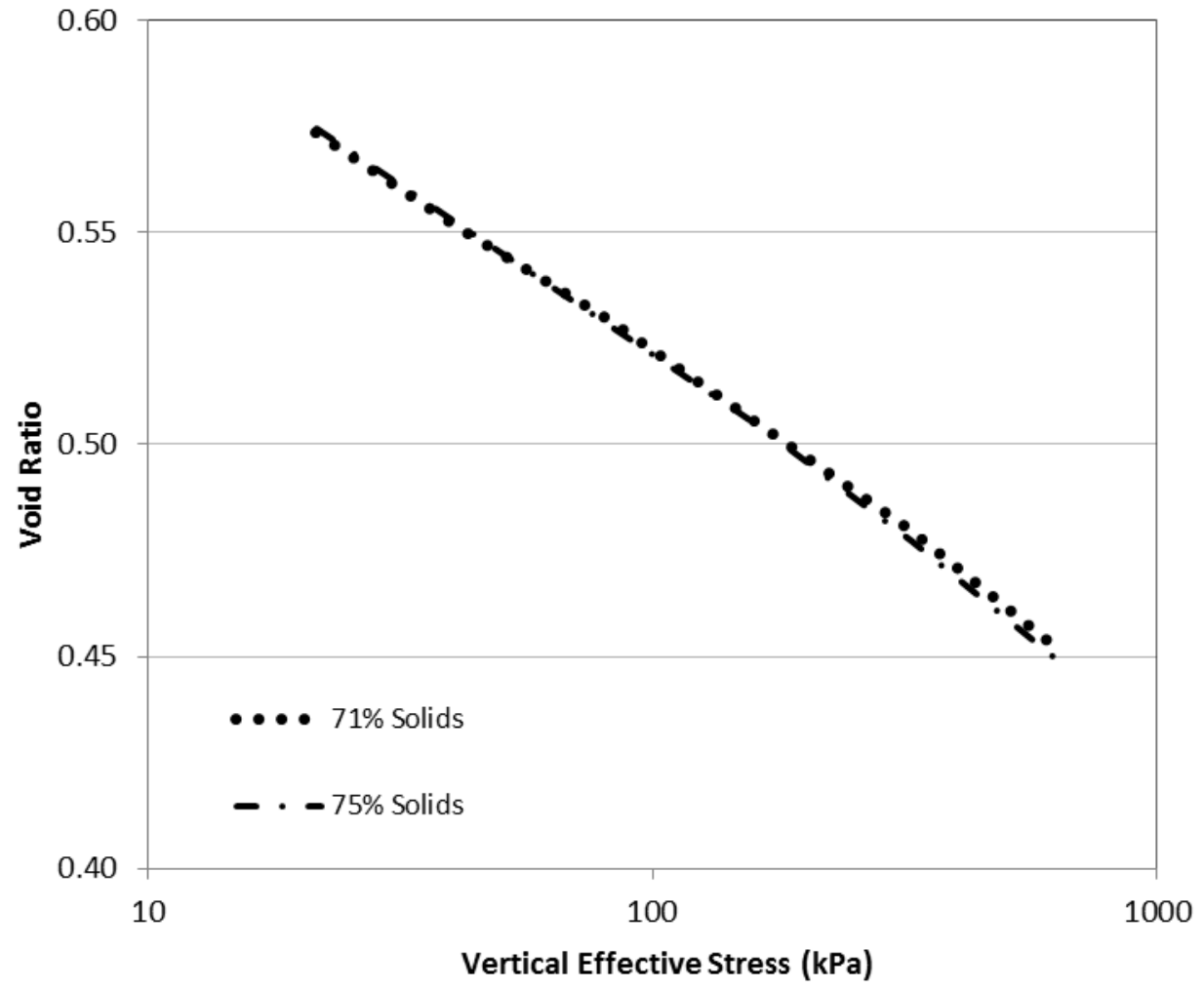

\section{Figure 6 Gold (1) tailings consolidation results}

The results obtained for lateritic nickel, iron ore, and gold (2) tailings tests are presented in Table 3 for comparison to similar studies found to support Hypothesis B. The tests undertaken as part of this study gave a dry density increase at $100 \mathrm{kPa}$ of $3-6 \%$. This is smaller than the average increase observed within the literature, but is within the range of results available.

\section{Table 3 Lateritic nickel and iron ore densities at $100 \mathrm{kPa}$}

\begin{tabular}{|c|c|c|}
\hline Tailings & $\begin{array}{l}\text { Range of slurry } \\
\text { density tested (\% } \\
\text { solids by mass) }\end{array}$ & $\begin{array}{c}\text { Resulting range in dry density } \\
\left(\mathrm{t} / \mathrm{m}^{3}\right) \text { at } 100 \mathrm{kPa} \text { vertical } \\
\text { effective stress }\end{array}$ \\
\hline Iron ore & $63-69$ & $1.91-1.97$ \\
\hline Lateritic nickel & $30-38$ & $0.93-0.98$ \\
\hline Gold (2) & $63-73$ & $1.65-1.72$ \\
\hline
\end{tabular}

To ensure that segregation was not influencing the results obtained, the lower slurry density lateritic nickel and gold (2) tailings samples were split after oven drying, and wet sieving was undertake for the bottom and top portion of each. The results are presented in Table 4. The gradation at the top and bottoms of the samples were nearly indistinguishable (within 1\%). Indeed, for the gold (2) tailings, the slight difference in gradation between bottom and top are the opposite of what would be expected based on segregation during settling. These results suggest that significant segregation had not occurred in the two tests. Further, the gold (1) and iron ore tailings tested in an oedometer were first observed at the range of slurry densities tested through clear settling columns, indicating that segregation did not appear likely for those materials. 


\section{Table 4 Sample gradations}

\begin{tabular}{ccccc}
\hline \multirow{2}{*}{ Particle size } & \multicolumn{2}{c}{ Gold (2) } & \multicolumn{2}{c}{ Lateritic nickel } \\
\cline { 2 - 5 } & Top & Bottom & Top & Bottom \\
\hline$<75 \mu \mathrm{m}(\%)$ & 60.7 & 61.8 & 87.8 & 87.2 \\
$<53 \mu \mathrm{m}(\%)$ & 44.6 & 45 & - & - \\
$<38 \mu \mathrm{m}(\%)$ & 31.9 & 32.9 & 69.1 & 68.1 \\
\hline
\end{tabular}

Sidewall friction may influence the results of slurry consolidometer testing (e.g. O'Kelly 2009) and is a function of sample height and stress. For the slurry consolidometer testing undertaken, the higher slurry density samples were of greater or similar height than the other sample for each material, at each stage of the consolidation test. Further, the stresses applied were identical for both samples. Therefore, the looser state observed for the lower initial solids samples is unlikely to be a result of increased side friction.

\section{$5 \quad$ Conclusions}

The influence of slurry density on the resulting density at increasing effective stresses was investigated by means of a literature review and consolidation testing. A review of published studies where consolidation tests were undertaken on material remoulded from different slurry densities indicated that in many cases, slurry density has been shown to increase density at a given vertical effective stress. For materials where this was observed, an average increase in density of $13 \%$ was observed at $40-100 \mathrm{kPa}$ vertical effective stress. This behaviour was observed for both tailings and natural soils.

Three sets of case history data for different tailings deposits was presented, with the available information examined for insight into the question posed by this paper. For each, there seems to be evidence that varying of slurry density may result in a unique $\mathrm{NCL}$, thus resulting in different densities at a range of vertical effective stresses.

Consolidation tests were undertaken by the authors on four tailings, prepared at different slurry densities. For three of the materials tested, a unique NCL was created by means of different slurry densities. The differences observed in these tests was similar to the range observed in studies within the literature.

On the basis of the work undertaken in this study, it is concluded that Hypothesis B is valid, at least for many types of tailings and natural soils.

\section{References}

Al-Tarhouni, M, Simms, P \& Sivathayalan, S 2011, 'Cyclic behaviour of reconstituted and desiccated-rewet thickened gold tailings in simple shear', Canadian Geotechnical Journal, vol. 48, no. 7, pp. 1044-1060.

Aydilek, AH, Edil, TB \& Fox, PJ 2000, 'Consolidation characteristics of wastewater sludge', in T Edil \& PJ Fox (eds), Geotechnics of Higher Water Content Materials, American Society for Testing and Materials, West Conshohocken, pp. 309-323.

Barrera, S \& Riveros, C 2006, 'Stability of tailings beach slopes', in RJ Jewell, AB Fourie, S Lawson \& P Newman (eds), Proceedings of the Ninth International Seminar on Paste and Thickened Tailings, Australian Centre for Geomechanics, Perth, pp. 169-180.

Been, K \& Jefferies, MG 1985, 'A state parameter for sand', Géotechnique, vol. 35, no. 2, pp. 99-112.

Been, K, Crooks, JHA \& Jefferies, MG 1988, 'Interpretation of material state from the CPT in sands and clays', Penetration testing in the UK, Thomas Telford, London, pp. 89-92.

Berilgen, AA, Bcer, P, Berlgen, M \& Ozaydn, KI 2006, 'Assessment of consolidation behaviour of Golden Horn marine dredged material', Marine Geores. \& Geotech, vol. 24, no. 1, pp. 1-16.

Bonin, MD, Nuth, M, Dagenais, A-M, \& Cabral, AR 2014, 'Experimental study and numerical reproduction of self-weight consolidation behaviour of thickened tailings', Journal of Geotechnical and Geoenvironmental Engineering, e-first article.

Chang, N, Heymann, G \& Clayton, C 2011, 'The effect of fabric on the behaviour of gold tailings', Géotechnique, vol. 61, no. 3, pp. 187-197.

Filho, WLDO \& Menezes, LP 2012, 'Consolidation relationships for different ore tailings in Brazil', Proceedings 16th International Conference on Tailings and Mine Waste, University of British Columbia, Vancouver, pp. 205-216. 
Fourie, AB 2012, 'Perceived and realised benefits of paste and thickened tailings for surface deposition', in RJ Jewell \& AB Fourie (eds), Proceedings of the 16th International Seminar on Paste and Thickened Tailings, Australian Centre for Geomechanics, Perth, pp. 47 - 46.

Fitton, TG \& Seddon, KD 2013, 'Paste and thickened tailings - myth busting and clarification', in RJ Jewell, AB Fourie, \& A Paterson (eds), Proceedings of the 15th International Seminar on Paste and Thickened Tailings, Australian Centre for Geomechanics, Perth, pp. 53-64.

Fourie, AB \& Papageorgiou, G 2001, 'Defining an appropriate steady state line for Merriespruit gold tailings', Canadian Geotechnical Journal, vol. 38 no. 4, pp. 695-706.

Fourie, AB, Blight, GE \& Papageorgiou, G 2001, 'Static liquefaction as a possible explanation for the Merriespruit tailings dam failure', Canadian Geotechnical Journal, vol. 38, no. 4, pp. 707-719.

Hong, Z-S, Yin, J \& Cui, Y-J 2010, 'Compression behaviour of reconstituted soils and high initial water contents', Géotechnique, vol. 60, no. 9, pp. 691-700.

Inparajah, D \& Wong, RCK n.d., '1-D consolidation characteristics of kaolinite-bentonite mixtures with different pore fluid salinity', Proceedings of the 61st Canadian Geotechnical Conference and 9th Joint CGS/IAH-CNC Groundwater Conference, Canadian Geotechnical Society, Richmond.

Ishihara, K 1993, 'Thirty third Rankine lecture: liquefaction and flow failure during earthquakes', Géotechnique, vol. 43, no. 3, pp. 349-415.

Jefferies, MG \& Been, K 2000, 'Implications for critical state theory from isotropic compression of sand', Géotechnique, vol. 50, no. 4, pp. 419-429.

Kam, S 2011, 'Thickened tailings disposal at Musselwhite Mine', in RJ Jewell \& AB Fourie (eds), Proceedings of the 14th International Seminar on Paste and Thickened Tailings, Australian Centre for Geomechanics, Perth, pp. 225-236.

Knop, A, Kno, LSI, Consoli, NC 2009, 'Compressibility of a residual soil when percolated by acidic waters', Proceedings of the 62nd Canadian Geotechnical Conference and 10th Joint CGS/IAH-CNC Groundwater Specialty Conference, Canadian Geotechnical Society, Richmond.

Li, AL, Been, K, Ritchie, D \& Welch, D 2009, 'Stability of large thickened, non-segregated tailings slopes', in RJ Jewell, AB Fourie, S Barrera \& J Wiertz (eds), Proceedings of the 12th International Seminar on Paste and Thickened Tailings, Australian Centre for Geomechanics, Perth, pp. 301-312.

Martins, FB, Bressani, LA, Coop, MR \& Bica, AVD 2001, 'Some aspects of the compressibility behaviour of a clayey sand', Canadian Geotechnical Journal, vol. 38, no. 6, pp. 1177-1186.

McPhail, G, Noble, A, Papageorgiou, G \& Wilkinson, D 2004, 'Development and implementation of thickened tailings discharge at Osborne Mine, Queensland, Australia', Proceedings of the International Seminar on Paste and Thickened Tailings (Paste 2004), Australian Centre for Geomechanics, Perth.

McPhail, G \& Brent, C 2007, 'Osborne high density discharge - an update from 2004', in AB Fourie \& RJ Jewell (eds), Proceedings of Tenth International Seminar on Paste and Thickened Tailings, Australian Centre for Geomechanics, Perth, pp. 339-350.

Meijer, G \& Dijkstra, J 2013, 'A novel methodology to regain sensitivity of quick clay in a geotechnical centrifuge', Canadian Geotechnical Journal, vol. 50, no. 9, pp. 995-1000.

Nocilla, A, Coop, MR, Colleselli, F 2006, 'The mechanics of an Italian silt: an example of 'transitional' behaviour", Géotechnique, vol. 56, no. 4, pp. 261-271.

O'Kelly, BC 2009, 'Development of a large consolidometer apparatus for testing peats and other highly organic soils', SUO - Mires and Peat, vol. 60, no. 1-2, pp. 23-36.

Papageorgiou, G 2004, Liquefaction assessment and flume modelling of the Merriespruit gold and Bafokeng platinum tailings, PhD thesis, University of Witwatersrand.

Reid, D \& Boshoff, J 2015, 'Stability of a proposed steepened beach', in RJ Jewell \& AB Fourie (eds), Proceedings of 18th International Seminar on Paste and Thickened Tailings, Australian Centre for Geomechanics, Perth, pp. 181-194.

Reid, D \& Fourie, AB 2014, 'Assessing the post-liquefaction shear strength of thickened tailings in the design stage - a review and update', in RJ Jewell, AB Fourie, PS Wells, D van Zyl (eds), Proceedings of the 17th International Seminar on Paste and Thickened Tailings, Infomine, Inc., Vancouver, pp. 429-444.

Rowe, PW \& Barden, L 1966, 'A new consolidation cell', Géotechnique, vol. 16, no. 2, pp. 162-170.

Sachan, A \& Penumada, D 2007, 'Effect of microfabric on shear behaviour of kaolin clay', Journal of Geotechnical and Geoenvironmental Engineering, vol. 133, no. 3, pp. 306-318.

Salfate, ER 2011, Predicting void ratio for surface paste deposited in thin layers, MAppSc. thesis, University of British Columbia.

Sanin, MV, Puebla, H \& Eldridge, T 2012, 'Cyclic behaviour of thickened tailings, Proceedings of the 16th International Conference on Tailings and Mine Waste, University of British Columbia, Vancouver, pp. 503-512.

Sheeran, DE \& Krizek, RJ 1971, 'Preparation of homogenous soils samples by slurry consolidation', Journal of Materials ASTM, vol. 6 , no. 2, pp. 356-373.

Siddiqua, S \& Blatz, JA 2009, 'Evaluation of the impact of pore fluid properties on the 1D consolidation behaviour of clay based sealing material', Proceedings of the 62nd Canadian Geotechnical Conference and 10th Joint CGS/IAH-CNC Groundwater Specialty Conference, Canadian Geotechnical Society, Richmond.

Shuttle, DA \& Cunning, J 2007, 'Liquefaction potential of silts from CPTu', Canadian Geotechical Journal, vol. 44 no. 1, pp. 1-19.

Strydom, JH \& Williams, AAB 1999, 'A review of important and interesting technical findings regarding the tailings dam failure at Merriespruit', Journal of the South African Institution of Civil Engineering, vol. 41, no. 4, pp. 1-9. 
Takada, N \& Mikasa, M 1986, 'Determination of consolidation parameters by selfweight consolidation test in centrifuge', in RN Yong \& FC Townsend (eds), Proceedings of Consolidation of Soils: Testing and Evaluation, American Society for Testing and Materials, West Conshohocken, pp. 548-566.

Vaid, YP \& Sivathayalan, S 2000, 'Fundamental factors effecting liquefaction susceptibility of sands', Canadian Geotechnical Journal, vol. 37, no. 3, pp. 592-606.

Vaughan, PR 1997, 'Panel discussion: sedimentation of tailings', Proceedings of the 14th International Conference on Soil Mechanics and Foundation Engineering, vol. 4, A.A. Balkema, Rotterdam, pp. 2561-2562.

Wagener, F 1997, 'The Merriespruit slimes dam failure: overview and lessons learned', Journal of the South African Institution of Civil Engineering, vol. 39, no. 3, pp. 11-15.

Wagener, F, Craig, HJ, Blight, GE, McPhail, G, Williams, AAB \& Strydom, JH 1998, 'The Merriespruit tailings dam failure - a review', Proceedings of the Conference on Tailings and Mine Waste '98, Colorado State University, Fort Collins, pp. 925-952.

Wang, YH \& Siu, WK 2006, 'Structure characteristics and mechanical properties of kaolinite soils. II, effects of structure on mechanical properties', Canadian Geotechnical Journal, vol. 43, no. 6, pp. 601-617. 